\title{
Constellations versus hero: a conversation with Mary Miss
}

\author{
Ed Wall
}

\begin{abstract}
By developing frameworks of carefully structured art, science, and urban community collaborations, City as Living Laboratory (CALL) forms constellations of projects that aim to make tangible and address environmental concerns, including the climate crisis, urban equity, and health. Founded by the artist Mary Miss, $C A L L$ denies the singularity and monumentality of many public art works to instead focus on 'constellations' of situated walks, conversations, and initiatives that lead to specific projects. This article, structured around an interview with Mary Miss, discusses the potential of art practices that organise to create change, empowering people and transforming marginalised landscapes. It reveals how such practices can make visible local environmental conditions while also addressing challenges of the climate crisis.
\end{abstract}

Keywords: Art, science, community, landscape, environment, climate crisis.

Note on the author: Ed Wall is an Associate Professor of Cities and Landscapes, and Head of Landscape Architecture and Urbanism, at the University of Greenwich. He is a Visiting Professor at Politecnico di Milano, and in 2017 was City of Vienna Visiting Professor: Urban culture, public space and the future-urban equity and the global agenda (TU Vienna). His research explores the intersection of environmental justice, urban public space, and design experimentation. Ed is guest-editor of The Landscapists: Redefining Landscape Relations (Wiley/AD 2020) and co-editor of Landscape Citizenships (Routledge 2021). He is the author of the forthcoming Contesting London: Urban Spaces, Social Lives and Redevelopment (Routledge 2022). In 2007 Ed founded Project Studio. Works such as Lubricity, Park Works, Roaming Forest, and the Valley Project have been published in the Guardian, Architects' Journal, Building Design, Abitare, and Arch Daily, and exhibited at the Van Alen Institute, Royal Academy, Building Centre, Garden Museum, and Des Moines Art Center. https://orcid.org/0000-0003-0505-7076 e.wall@greenwich.ac.uk/www.projectstudio.co.uk

(C) The author(s) 2021. This is an open access article licensed under a

Creative Commons Attribution-NonCommercial-NoDerivs 4.0 Unported License 
Since she trained as a sculptor in the 1960s, Mary Miss's art practice has evolved with consistency and clarity. From her feminist activism in the late 1960s to her acclaimed environmental art produced since the 1970s, Mary Miss's works can be read as always confronting prevailing social and environmental inequities from the ground up. Born in New York City, she is considered one of the pioneers of site-specific art practice, making an impact on her home city with projects such as Battery Park Landfill (1973), South Cove (1988), and Framing Union Square (1998). Mary Miss's work is often discussed in the context of environmental artists, such as Robert Smithson, Robert Irwin, Robert Morris, and Alice Aycock (see Rosalind Krauss 1979), but her work that intersects sculpture, architecture, landscape design, and urban design tends to draw closer relations with concerns for public spaces and public spheres. Reflecting her role as a member of HERESIES: A Feminist Publication on Art and Politics (1973-1993), a magazine that combined issues such as art theory, violence, racism, sex, and politics, she has contributed to feminist discourses through her social, ecological, and situated art practice. As concerns for sustainability and the climate crisis have become more pronounced Mary Miss has initiated works that defy the singularity of sculptural objects - what she terms 'monoliths' - to mobilise artists, experts, agencies, residents, and landscapes as 'constellations' (Interview 2021). City of Living Laboratory (CALL) is the latest phase of Mary Miss's work, a 10-year project that is part framework, part community, part facilitatory network, part installation. As a project of projects, $C A L L$ aims to bring together artists, scientists, and urban communities to address a range of environmental issues, including the climate crisis, urban equity, and health.

This article is structured around a conversation with Mary Miss in March 2021. I first met her when she was developing the Park as Living Laboratory (2005-2006) proposal for the Orange County Great Park, in California (see Figure 2). The proposal that was part of a winning competition entry was never realised, but Mary Miss recognised its potential for developing dialogue with artists, scientists, and community residents as a means to bring people closer to the planned infrastructures and urban ecosystems of their landscapes. From Park as Living Laboratory Mary Miss initiated $C A L L$, in 2011, as a testbed and incubator that could further the ecological ideas and conversations around sustainability. I was keen to explore in the interview how the ideas she had brought together fifteen years earlier in Park as Living Laboratory could suggest future urban practices that can make visible localised environmental challenges while also providing a potential means to address the climate crisis. How can art practices mobilise to create change in ways that empower situated lives and transform urban landscapes to address the climate crisis? While Mary Miss's work can be contextualised amongst other artists, such as Miele Laderman Ukeles who has developed an art practice focused on 'maintenance' (see Ukeles 1969) and who has been 


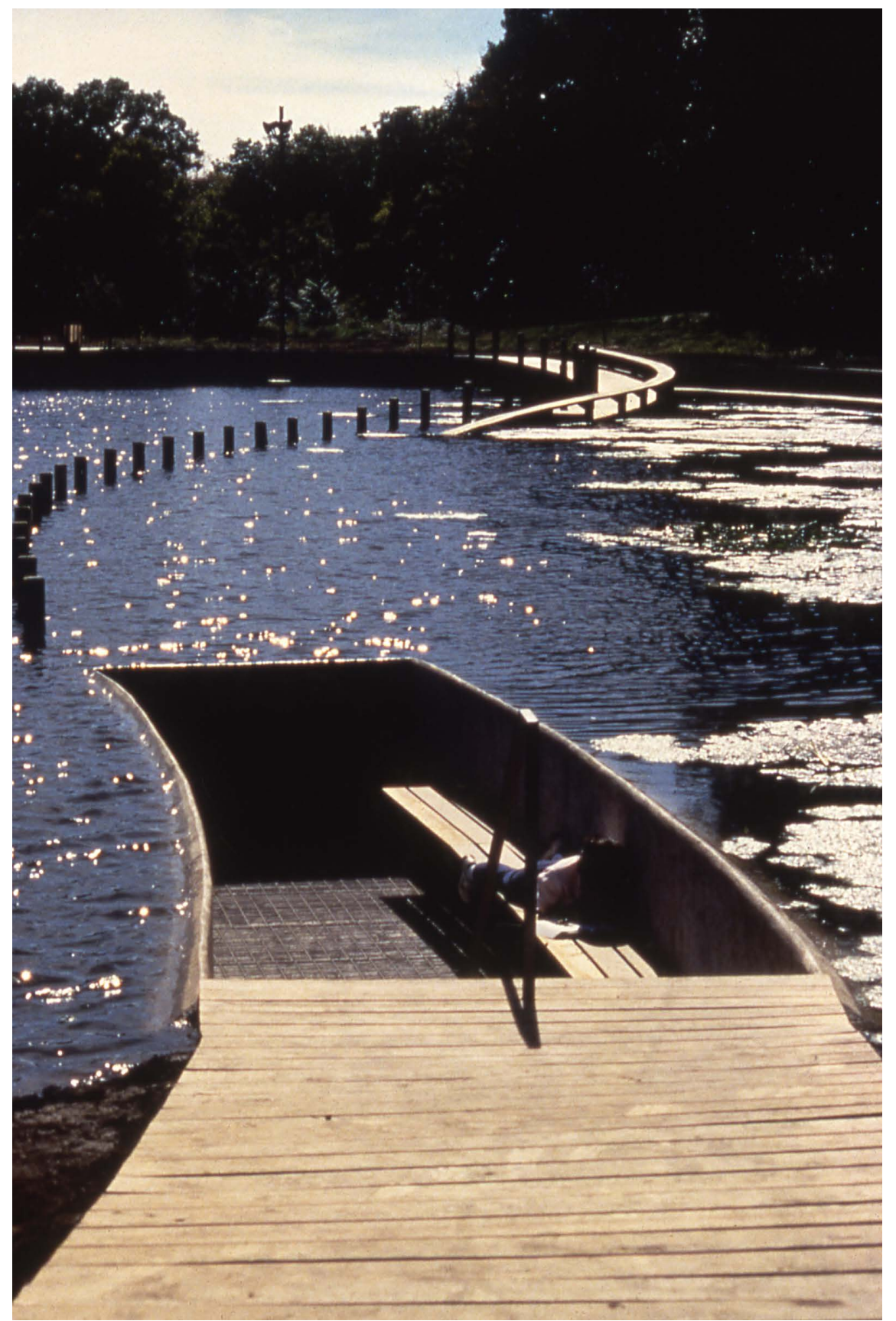

Figure 1. Greenwood Pond: Double Site (1989-1996). 

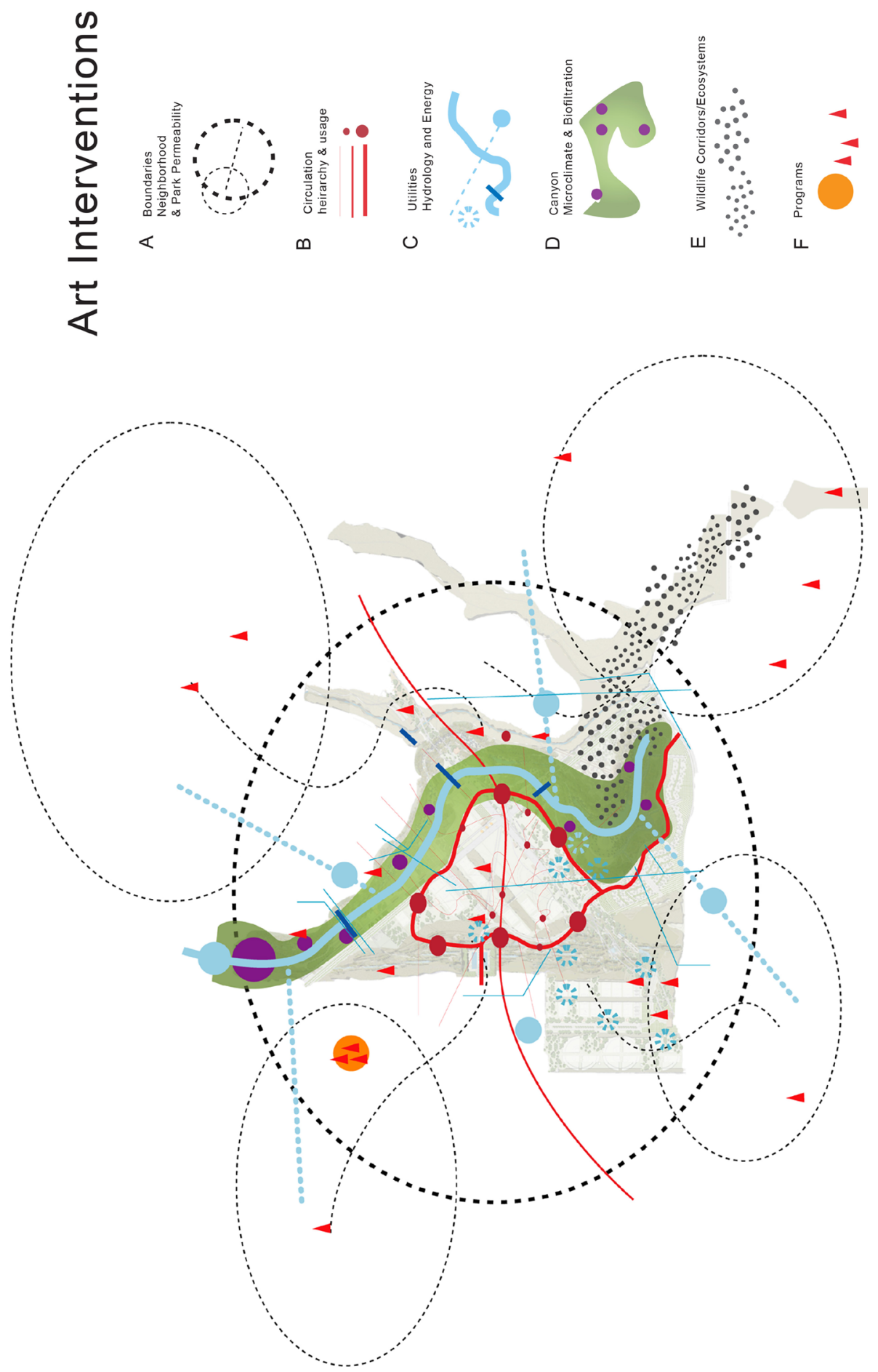
artist-in-residence at the New York City Department of Sanitation, Mary Miss's work forms a unique practice that is engaged with communities and neighbourhoods as a basis to enact change.

$C A L L$ is a framework for art, science, and community collaborations that uniquely connect grounded environmental issues within communities to global agendas for climate justice and sustainability. The approach works with, between, and from neighbourhood actions - in cities like Milwaukee - to global agendas, such as UN Sustainable Development Goals. It is structured around four core initiatives, including: walks, workshops, proposals, and projects. The initiatives can be read as sequential stages - inclusive of community members, neighbourhood schools, artists, scientists, policy makers, and funding bodies - that lead to the development of site-specific projects. The walks are situated public engagements led by scientists or other experts along with local citizens and communities, and provide a means of developing awareness, sharing stories, and revealing environmental concerns. The walks aim to raise awareness of environments less visible or threatened, whether culverted rivers or polluted landscapes. Workshops often follow the walks, as the basis for more in-depth conversations, with communities facing challenges such as the climate crisis. The workshops provide opportunities to share stories of places, especially revealing otherwise excluded narratives of living within marginalised or threatened landscapes, while proposals are commissioned based on information gathered during workshops. Proposals are then tested within the $C A L L$ process in order to realise projects that draw together and work between many different residents, stakeholders, and governance agencies.

Mary Miss aims to provide a platform to work with young artists to inform the projects, developing networks of individuals across the communities and within the $C A L L$ framework: 'We see artists as leaders who can inspire greater community understanding in the journey toward sustainable living' (Watermarks 2021). For $C A L L$, the term 'sustainability' encompasses a range of responses, from the Watermarks project, where CALL commissioned Melanie Ariens to develop the 9 Pillars Mural with students from a Milwaukee high school, to Harlem/Designing Emergency Preparedness where CALL collaborated with WeACT for Environmental Justice resulting in a proposal by the landscape architect Elliott Maltby. In 2021, as COP26 convenes around the United Nations Framework Convention on Climate Change (UNFCCC), CALL marks its 10-year anniversary. With its unique approach in situating environmental action within global agendas, this article reflects on the strategic art practice of $C A L L$, through a reflective conversation with its founder, Mary Miss. ${ }^{1}$

${ }^{1}$ Conversation between Mary Miss and Ed Wall, 8 March 2021 [online]. 
[Ed Wall] I don't have any specific questions; I am just interested to hear about City as Living Laboratory [CALL]. In the context of informing the future of climate change and cities, I am fascinated by $C A L L$ as a series of public actions, discourses, and ecologies.

[Mary Miss] You know, we [first] met at a particularly complicated time in my working life. I had spent so much time in the '90s developing projects that didn't happen. As we all know, it's complicated to get a project through the public realm unscathed but it is especially true for artists. It was just very frustrating to spend years, quite regularly years, developing something like the plan for the sewage treatment plant in Arlington, Virginia, or, various [other] projects, that don't happen.

I think a key experience for me was after 9/11 - you know my studio is right down there near the World Trade Center site - and we did a proposal in my studio, for the perimeter of the site and a temporary memorial [see Figure 3]. And somehow it just really clicked for me that I wanted to be working on things that, could be done quite easily and where there was some modesty to the elements. It was in New York City addressing a neighbourhood that I was very concerned about, my own. That was a key thing to triggering my feeling, that I had to start doing projects where it was possible to actually get something done - and that I wanted to be able to address issues in places that I was really concerned about and interested in.

Then, in the early 2000s, working on the Orange County Great Park, another project which did not materialise, I developed the Park as Living Laboratory idea. And when that didn't happen, I had the opportunity, because of money received for another cancelled project at the Indianapolis Museum of Art, to think about how the Park as Living Laboratory could be developed for cities.

So that was the process I went through, but it was really responding to how difficult it is as an artist to get completed projects out in the world. Also, I've always felt, any time I've done any visiting teaching or doing crits, there are so many interesting ideas that young people are developing in studios, and then they get out of school and go and work at the back desk in an office. And I really thought it was so important for the ideas and thinking of young artists and designers, and not so young ones, to be able to get out on the street.

At the same time, [Michael] Bloomberg was the Mayor [of New York City] and coming up with very ambitious plan for making New York City sustainable. But all of that work was happening at the level of departments and agencies and I really felt that [it] was so important to get things out on the street. So those were the various things that I was responding to. 


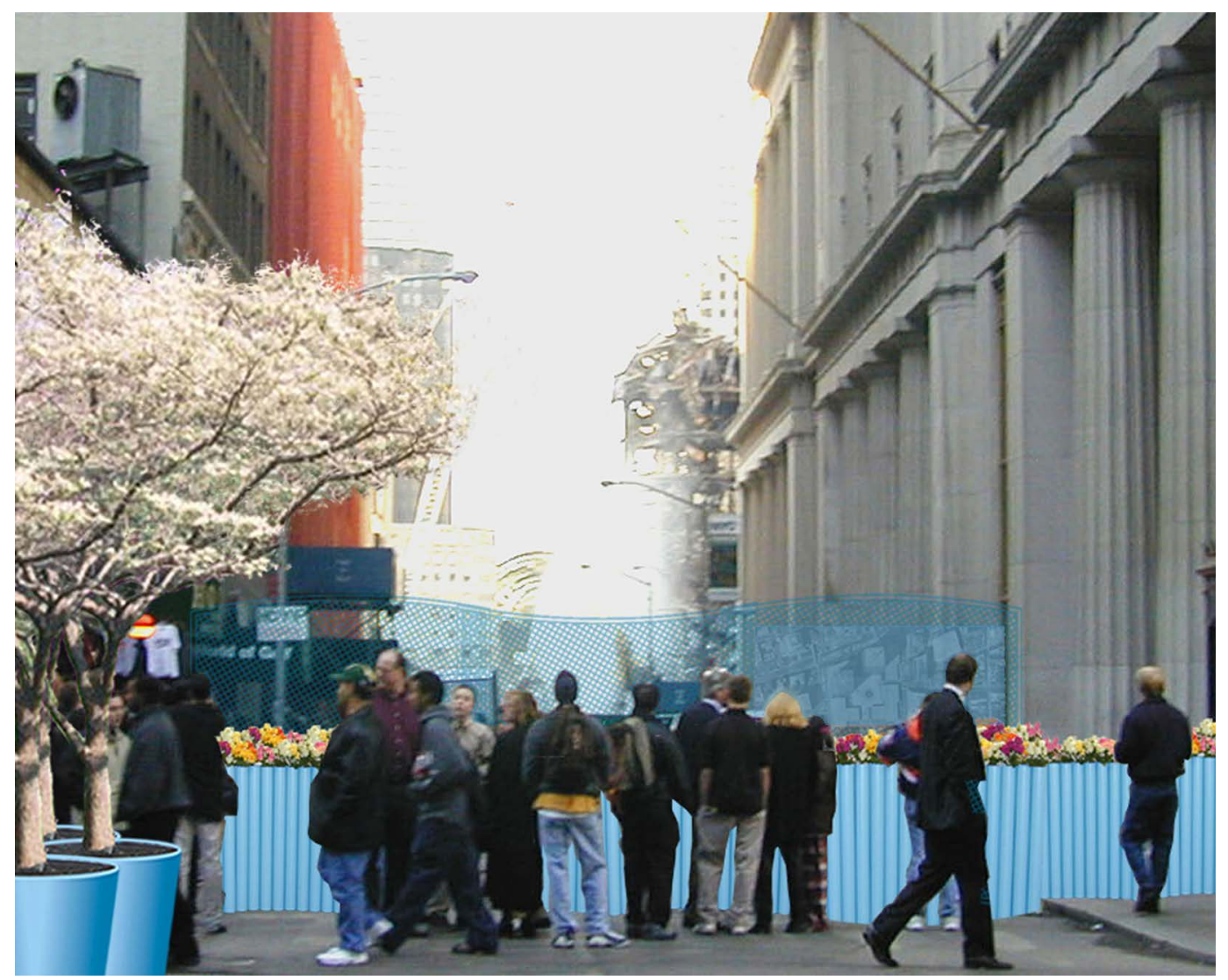

Figure 3. Moving Perimeter (9/11 memorial).

$[E W]$ The methods, Mary, with which you begin the projects [that are part of $C A L L]$, include walks and conversations. They are the beginning of a structured approach that appears to have been developed from your earlier art practice.

[Walking has been central to Mary Miss's practice, as a way of engaging with issues, mobilising people, and creating change. It is also an approach that connects her early activism around inclusivity of women artists in New York galleries, such as the Whitney, to the specifically structured initiatives of $C A L L$. In an unpublished paper that Miss presented at the AIANY (American Institute of Architects New York), she explains 'Walking was not an experience to be taken for granted. I knew that it was a privilege and one that I did not necessarily get to share ... Perhaps because it was fraught, walking became a core practice. It was how my activism was expressed in my work' (Miss 2021). As with Mary Miss's early environmental art works, the walks of $C A L L$ resonate with walking artists such as Richard Long and Hamish Fulton. However, the collective nature of the walks that $C A L L$ organise and the focus that each walk follows contrast with the documented walks of Long's $A$ Line Made by 
Walking (1967) or Fulton's Pilgrims Way (1971). Instead, CALL's walks reflect the fieldwork approach of artists such as Katie Etheridge whose Reimagine Your Town (2016) involved walking with others, providing moments for sharing experiences and stories of places, while looking closely at landscapes participants were already familiar. Importantly, however for the $C A L L$ projects, the walks, workshops, and proposals are the means to which urban change can be realised through projects.]

$[M M]$ Well, I just wrote something on walking for a panel at the AIA [American Institute of Architects] here in New York. It was interesting to reflect back to my earliest work. There's a project that I did in 1968, or '69, where there were ropes, every 20 feet that were anchored, pulled taught and staked along the southern edge of Ward's Island in the East River. And I was remembering back to that time, and what movement meant to me, what mobility meant to me. As a young artist, I very much had a sense that I was not interested in the monolith or the monument. I was looking for new ways to work. I was a part of this mobilisation of women, to change things. Movement became a very important aspect of the work [then] and that has gone all the way through to the present day. Walking as a young woman was a very complicated thing in New York City - I saw it as a privilege that I could not easily share. The City was tough at the time and it was difficult to be out on the streets, after a certain hour. So, all of those things kind of drew me to walking as being integrated into my practice. It's interesting that Broadway 1000 Steps [one of the first CALL projects; see Figure 4] is based on this idea of walking. Until I sat down to write this, I hadn't, quite thought it through. But it was interesting to trace my own 'steps'.

\section{$[E W]$ And with that walking, they seem to be educational, is that fair to say?}

$[M M]$ I think that they're observational ...

Well, first of all, I think that we acknowledge that walking is something that we don't all get to share equally, and you know, what colour you are, what your mobility is, will all depend on what it's like for the individual. But for me, it's that kind of direct experience, and being in the world, seeing things, observing, smelling, hearing, that makes walking so compelling. At the same time, the walks are a way we could begin to introduce ourselves to neighbourhoods in the Broadway project [Broadway 1000 Steps], and introduce neighbourhoods to us, and introduce artists to scientists or historians or others. And, so, this was a very practical way to begin an exploration.

$[E W]$ Was the move from walks to workshops [the first two stages/initiatives of the $C A L L$ approach] more of a grounding of the activities of walking?

$[M M]$ As we would do these walks, it became clear we were aware of only some of the issues that communities were facing. If you come as an outsider into Chinatown [in 

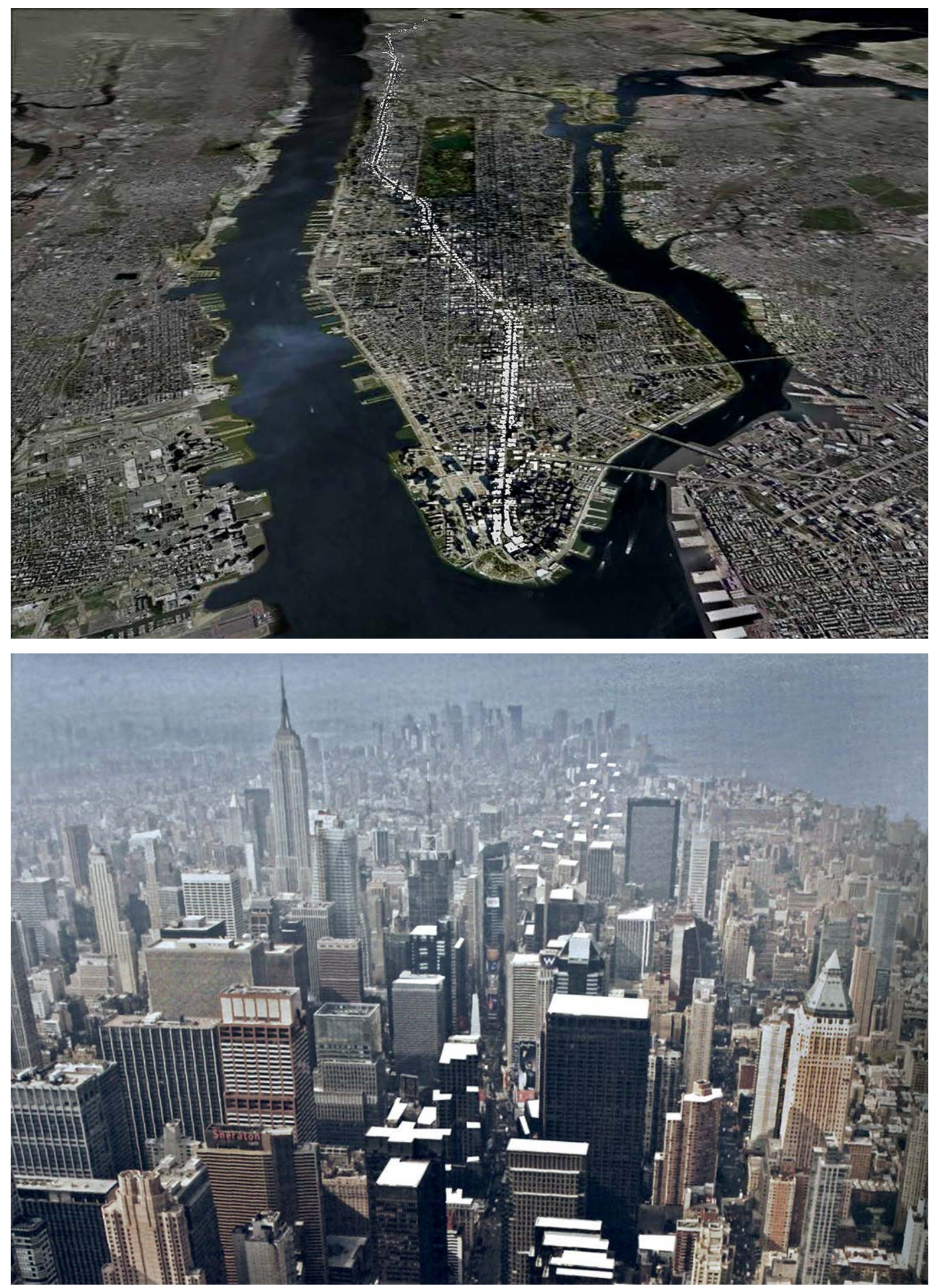

Figure 4. Broadway 1000 Steps [City as Living Laboratory]. 
New York City], especially where you can't easily have access with so many languages being spoken, not to mention that they're difficult languages. Or walking on the streets of Harlem, how do you become more familiar, beyond a superficial sense, with what's going on? I think that the work we're doing in the Bronx is an interesting example, we had a number of walks there. But then, during an early workshop that was in 2016 we became aware of the flooding that was caused by Tibbetts Brook, a stream that was put into the Broadway sewer [see Figure 5]. It's an issue that the Bronx Council on Environmental Quality and the Community Board had been working on for a decade and a half, but nothing was happening with it. So, through that workshop, we really began to focus on this issue to see how we could help draw attention to it.

The state finally got interested in this issue that the City Department of Environmental Protection did not have the means to pay attention to. The State realised that this was the worst sewage overflow into a waterway in New York City, [and it] goes into the Harlem River. And if they could fix this, they could go a long way towards meeting the Federal consent decree that they had to deal with. We are all interested to make sure this ends up not only as an engineering solution but something that will be an amenity to the community. The proposal is to divert the stream away from the sewer into a nearby rail corridor; this offers the opportunity to create a linear park in the old CSX Rail tracks.

So, the workshop is really a way to begin to get at the issues. In Chinatown there was a workshop we did and one of the artists who attended, Jean Shin, heard from people at the workshop about their interest in Chinese medicinal plants. And Jean came up with a really interesting way to address greening that area of the city, which has narrow sidewalks and so little planting space available. She designed window planters made out of recycled bottles that could hold medicinal plants. If you imagine the windows of Chinatown filled with greenery, that could really change the feeling of the place.

So, [the workshops are] a pathway into knowing more.

$[E W]$ In the context of City as Living Laboratory, I have been imagining a move in your practice from your early work that is materially and spatially distinct to something in $C A L L$ which is more ephemeral, non-material, more social, more relational. Is this something that you also see? Is it intentional?

[MM] Well, I would have loved to be able to keep building things in the world, but it just was not possible. One of my favourite projects that I did was in Des Moines, Iowa, where there's a cut in the water, and you can sit at eye level with water, and that kind of direct experience is so compelling to me [see Figures 1 and 6]. 


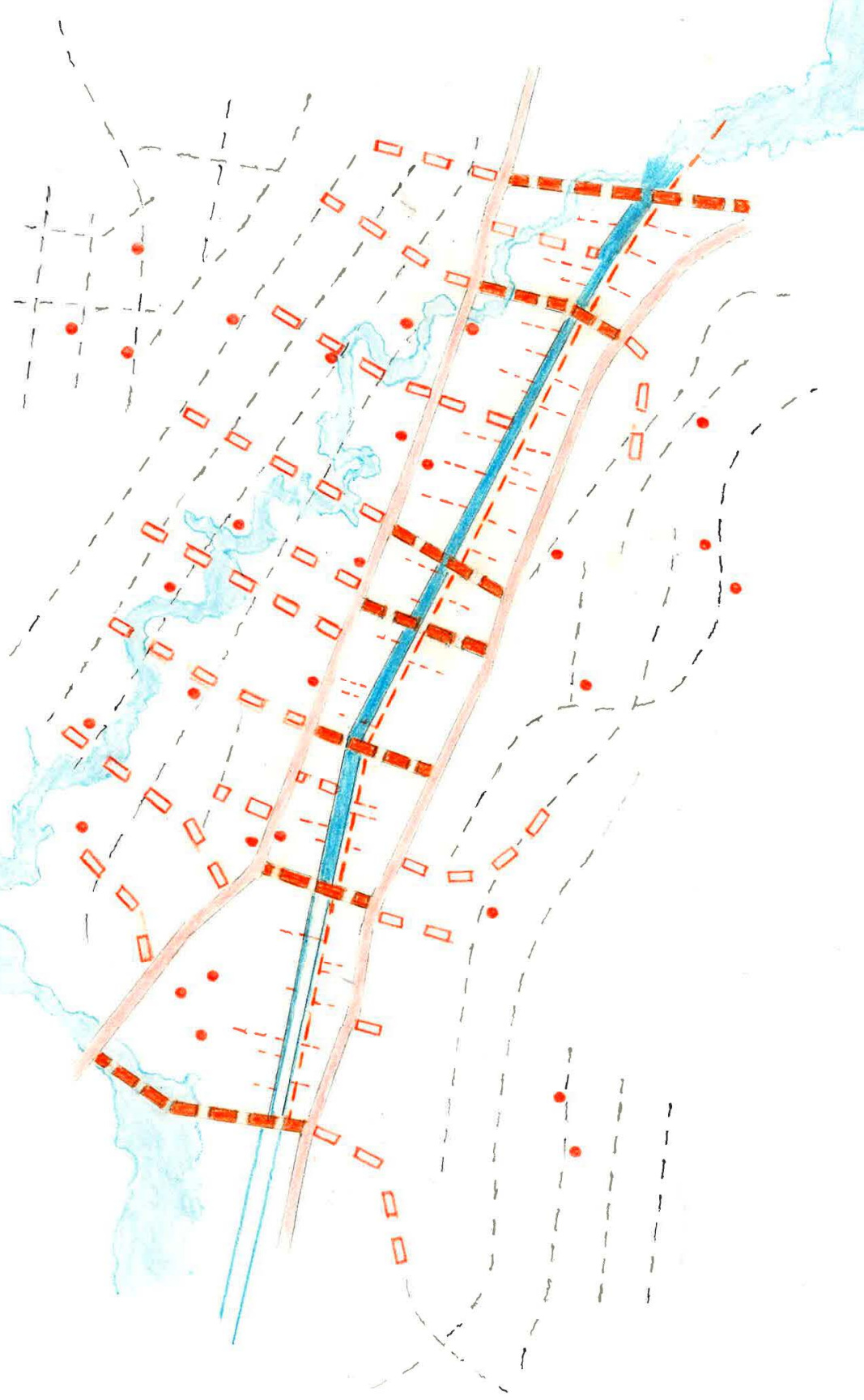

Figure 5. Rescuing Tibbetts Brook. 


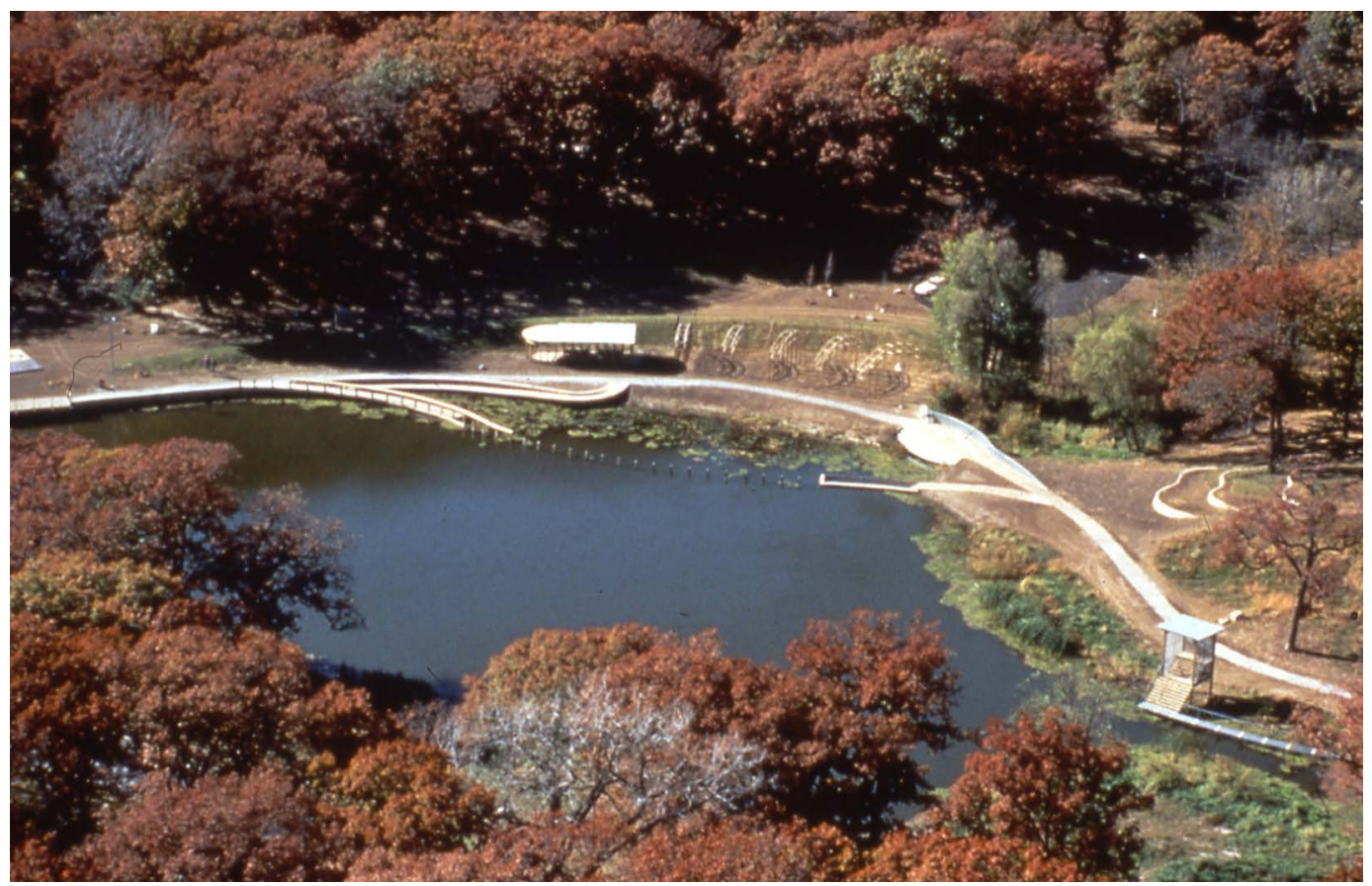

Figure 6. Greenwood Pond: Double Site (1989-1996).

[The description that Mary Miss provides reveals a combination of both a pragmatic response to the struggle in getting larger commissions and projects realised and also a recognition that, in the form of walks and workshops, the social and political relations that come to form the work are more prescient than the physical forms of the installations. Mary Miss's criticism of 'monuments' and 'monoliths' resonates with a critique that Ukeles developed in A Manifesto for Maintenance Art 1969 (1969). In the written work, Ukeles highlights the contradictions in what she terms 'development' and recognises the significance of 'maintenance' as facilitating development. Similarly, the four stages of CALL, in walks, workshops, proposals, and projects, are about the social and ecological processes required to bring about change. They entangle Mary Miss's art practice in places, with people, and into infrastructures, and organisations. It appears a messier practice than the recognisable and well photographed work that marks the early part of her career. But the ambition to work between artists and scientists, with communities, and inside of city agencies creates a capacity to make change in the lives of residents as well as wider environmental scales: 'This work is very process oriented and, like walking itself, takes time' (Miss 2021).]

[MM] In this past decade, there are six $C A L L$ projects I've developed, and with each it's really about developing a conceptual framework and then looking to other artists to expand and build upon them. The thing that has become so interesting to me is that if we're going to address the complex issues that we face, it has to happen at scale, it 


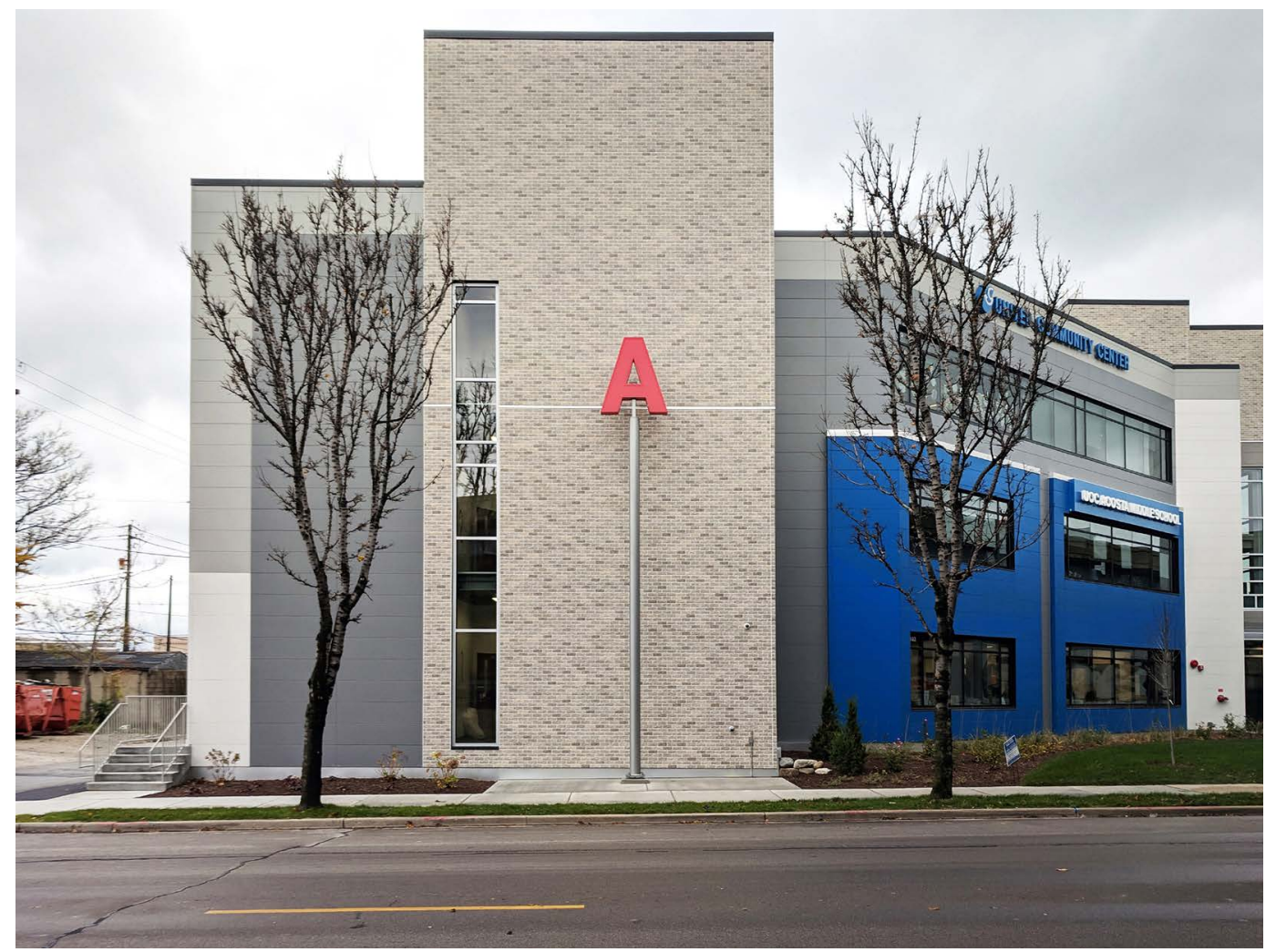

Figure 7. Watermarks [City as Living Laboratory].

can't just be individual projects. It's not about the heroine or hero coming up with the ultimate solution. What we really need is a constellation of artists and designers and thinkers, working across neighbourhoods and across cities.

The Watermarks project in Milwaukee is a good example of providing this kind of framework. It's a conceptual work as much as anything: the goal is to create an atlas of water for the city where physical markers call out specific issues. Each marker is intended to be a stake in the ground, so that the conversation doesn't go away. And other artists do projects at each of the sites to help get people's interest. Our next step in this process is trying to understand how we can engage communities and keeping these sites active over time [see Figure 7].

[Watermarks is a CALL project in Milwaukee that aims to create a city-wide engagement with water and water infrastructure - 'An Atlas of Water' (www. watermarksmke.org 2021). One of the projects that have been developed from the walks, workshops, and proposals is a series of markers that aim to connect residents and communities with the complex and layered systems of water that are essential to 
their lives. The project illustrates Mary Miss's interest in constellations of works, where the markers are installed and designed in collaboration with a high school, a neighbourhood action group, a university department, water industries, business districts, and environmental coalitions. The markers go beyond the role of urban landmarks or signs that inform or orientate citizens (see Lynch 1960), they connect, raise questions, reveal, and add to the stories of places.]

$[M M]$ So yes, it's relational in so many ways and I've learned so much. In the beginning my main focus going into a project was how we can get people to focus on the environment, and their relationship to it. Within a very short period of time, it became clear to me how equity and environmental justice issues were so often at the heart of this work. As soon as we started looking at the corridor of Broadway, it became apparent that some of the worst problems are in the most underserved neighbourhoods.

There are many interests that have carried over from the earliest work, but there is definitely a shift, as I started the $C A L L$ projects.

$[E W]$ You mentioned environmental justice there. The publicness of the work, starting with these walks, which seems to be within a public realm, working collectively, talking about issues which are highly political, and at the same time, you describe [on your website] the significance of the UN Sustainable Development Goals (SDGs). What scales are you able to work at Mary, with the infrastructure or the framework that you've put in place?

$[M M]$ It's really a good question. First of all, I started having regular conversations with a number of key scientists a few years ago that were very formative and have been really important to me: ecologist Eric Sanderson was particularly helpful in understanding how to look at the history of the ecology of a place. I don't know if you know, the work of Steward Pickett, but his work on urban ecology sets many great precedents. And the social ecologist Adrian Cerezo helped me think more about complexity, and how artists and art making is made to take it on. Artists are used to complexity it's something we deal with all the time. Conversations with Adrian brought me to focus more specifically on the UN SDGs. It quickly became apparent that they provided a set of useful lenses to focus the work we were doing.

And my goal is to make experiences available to people that allow them to take on particular aspects of the very complex set of issues that we face. But I also came to realise how interrelated these issues are. In Milwaukee, this large-scale urban project about water is definitely about more than water. It is about health, it is about jobs, it's about equity, all of these things are really interrelated. It's been such an interesting learning process for me as I've developed these projects, coming to understand the implications of them.

A couple of years ago, we had a meeting with various groups we had worked with [on $C A L L$ projects] over previous years. The scientists were very excited about the 
walks and said, 'Oh, we should start doing these all over the country - you know people in the arts and we know scientists.' Since there were only three of us working in the studio at the time it seemed a bit overwhelming. But we got a grant from the National Endowment for the Arts, and did six walks across the country in Santa Fe, Pittsburgh, Washington DC, Baltimore, Milwaukee, and New York. From this set of experiences we developed a workbook about how these walks can be organised. We really aspire to be able to get these happening in different parts of the country. So we do think about this work at different scales.

In Milwaukee, we've just applied for a large National Science Foundation grant; they are very competitive but we have been lucky enough to have two in the past. One of the things we would really like to do (in addition to installing more markers in neighbourhoods across the city) is to develop a document that would note the process we are going through. We would like to lay out a path for other cities or communities to take on urban scale projects. We aspire to be able to pass this knowledge along. Somebody said of this project recently, 'isn't this overly ambitious?' And I thought, 'Well, you could say so.' But I feel this is work that has to be done. The problems we face are so pressing. As an artist, I felt like nobody was letting me do the things I wanted to do so I can just dream projects up myself and who's to stop me. I can be overly ambitious if I want to be.

$[E W]$ It seems like there's an opportunity, if it's not already happening with your work, to almost run in parallel with traditional forms of governance, where you are feeding into and challenging the way in which decisions are made about sustainability and climate change.

$[M M]$ I think that is true. I am really so pleased with the way the project in Milwaukee is evolving because a full process is being developed. Milwaukee is one of the most segregated cities in the US and it has huge problems. It's north of Chicago on Lake Michigan and is one of those places where the industries left and communities fell apart. I had worked there in the late 90s and when I went back in 2014, I couldn't believe the changes: the downtown area was full of new housing, the river was accessible, cleaned up. But many parts of the rest of the city were as underserved as ever. And yet, at the same time, it has this old socialist history, going back to the end of the 19th century and there are people there who are really trying to make change, and who are really willing to put in the time to do that. And that's allowed us to pull together a great group of individuals and organisations to do this project. There are people from the university, city government as well as neighbourhood organisations. The head of the municipal sewer district, a very remarkable man, is the person who encouraged me at the beginning of the project to make this an urban scale project. 
It's not as though anyone was offering a large sum of money beyond an initial design fee. In fact, we are the ones who've been raising a good part of the money for the project - little City as Living Lab. But I'm able to work with city government, with agencies like the sewer district, with academic institutions, with organisations, NGOs, neighbourhood groups, and these groups are all decision makers. At this point, we've been able to bring them together as a working group, a coalition. We're finding out what people want and need with neighbourhood project teams. We're finding artists in those neighbourhoods who are very interesting. We're mentoring young artists there. A process and a means of decision making has been developed as the project has evolved. We are, I believe, coming up with means of making issues about climate change accessible and decisions about what to focus on available at the neighbourhood level.

Each of these markers across the city provides access to the stories neighbourhoods have to tell and where they can say to the city what's needed. They become points where the citizens can find out what's going on. It's no longer that these places are totally invisible; you get to see this network that appears from the lakefront spreads through the city. This is the goal.

I think this project is changing how you make things visible and apparent. One of the most important aspects is the stories we're collecting from all these neighbourhoods. When I started out as a young woman artist, one of the things that was so frustrating was that there were no women in the art books that I was looking at. I did not see myself reflected in the world around me - the statues, the street names. The public realm was such a monotone place, without reflecting the diversity of experience, the varied histories of those living there. We have been working with a young journalist in Milwaukee, who does interviews and finds these great stories that we're collecting and archiving. And each site becomes a Wi-Fi hotspot - in many of these neighbourhoods Wi Fi accessibility is not that easy. We are part of this slow braiding together of opportunities and groups.

\section{$[E W]$ Yeah ...}

$[M M]$ It's happening.

$[E W]$ But the markers [artworks] also quite striking objects. There is something very physical about their presence, which I quite enjoy. I think it feels like you, it feels like your work.

$[M M]$ The markers function in another way as well. They form the 'network' that radiates out from the central marker which is the stack at the Jones Island Water Treatment plant [see Figure 8]. The stack will be lit with moving light similar to what you see when light is reflected against a surface through moving water. The vapor from 

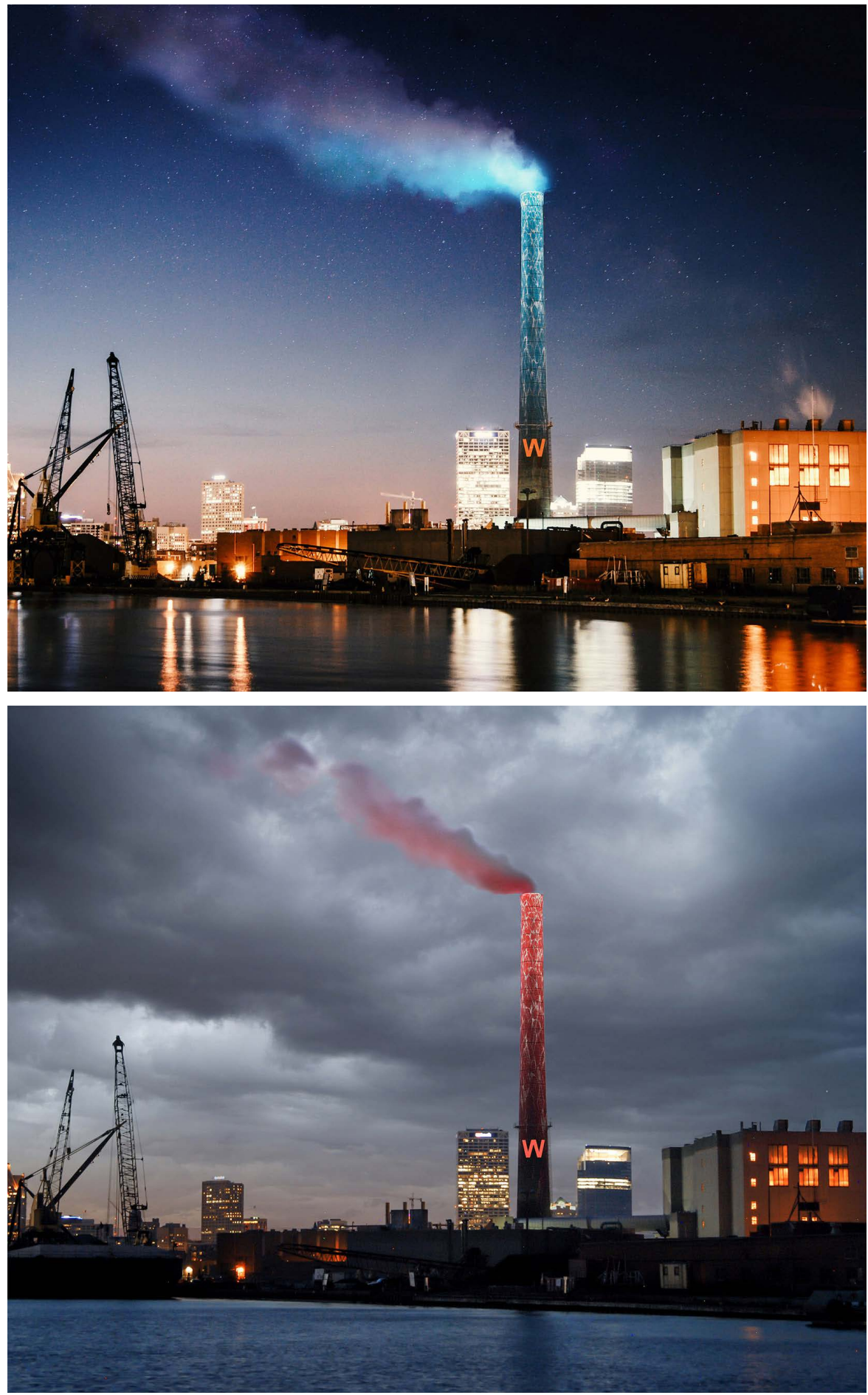

Figure 8. Watermarks [City as Living Laboratory]. 
the stack will be lit as well. It will be lit blue during normal functioning of the plant; when there is heavy rain and a threat of a sewerage overflow into Lake Michigan, the stack will be lit red. This is a warning for the residents of Milwaukee not to use their washing machines, to wait on having a bath, to limit heavy uses of water. This makes all the residents of the city into part of its 'green infrastructure'. The letter at the top of each marker of the network pulses when there is a threat of an overflow so that people across the city can participate.

At the beginning people were saying, 'Oh, what are those letters?' I thought of them as creating a kind of 'atlas' where the letter represents each community. The first that went in was at a Latinx Middle school and the children selected the letter 'A' for 'Agua' and the grade they wanted to get. For the next marker that's going in, the ' $\tilde{\mathrm{N}}$ ' was selected to represent that Latinx community. They want people to know how the neighbourhood identifies itself.

$[E W]$ I like the term markers that you use as well, because it provides an opportunity for the project to continue to spread. It's not something bound by a spatial envelope.

[The dispersed nature of the installations of Watermarks and other CALL projects an approach also evident in Park as Living Laboratory - form new infrastructures. The 'markers' defy traditions of framing landscapes (see Wall 2017) and engage with places as fields, across which constellations of markers can be read. The fields also provide a context for the walks that bring together people and practices: 'We want to find ways to connect people to the pressing environmental and social issues they face on the streets in their own neighbourhoods through direct experience. We want to work to begin to create new paths, to see new possibilities, to imagine resilient futures' (www.watermarksmke.org 2021). The field can thus be read as both the horizontal plane of landscape as well as the location and formation of the contrasting practices of CALL. In her seminal essay 'Sculpture in the Expanded Field' (1979) Rosalind Krauss sets out challenges to prevailing art practice, beginning with a description of Mary Miss's Perimeters/Pavilions/Decoys (1979: 30). Later in the essay, and as if anticipating the work of $C A L L$ in 2021, Krauss writes: 'Thus the field provides both for an expanded but finite set of related positions for a given artist to occupy and explore, and for an organization of work that is not dictated by the conditions of a particular medium' (1979: 42).]

$[E W]$ You've mentioned gender a few times, Mary, and I'm aware of your contribution to feminist art practice. How does that relate to City as Living Laboratory and the work you continue to do? And also, climate change, how does your work around gender relate your concerns for such global challenges?

$[M M]$ I think the whole undertaking is reflective of gender in a way. I can't tell you how uninterested I was as a young woman to see another monolith go up, or another 
monumental anything standing like a signpost. I just felt that there had to be a different way of doing things. And, also, that everything didn't have to be about me, you know, the whole idea of the City as Living Lab, is my trying to convince people that artists should have a place at the table, as we address the complicated crises that confront us. The first decade of City as Living Lab has been laying out these six conceptual frames of projects; I hope the next decade will focus on fleshing those out with projects by other artists. I think this sense of the constellation as opposed to the hero / heroine who solves everything alone, is something that comes out of experience and thinking as a young woman in the ' 70 s.

As far as issues around the environment relating to a feminist practice, it's hard for me to articulate. It's been an interest of mine from the very early years on, looking at the collision between the built and natural environment. Anything I say seems corny to link to feminism: care, caring for place. I think, really, the main thing is about moving out into the world - the walking that I spoke of earlier - and my desire to look at things from a different perspective than what I had previously seen around me. And to try to create intimate connections with our surroundings. Once you start to look at a place or situation closely, problems (as well as pleasures) soon become evident.

$[E W]$ It comes across very strongly in your work, and I think that maybe it's a sign of a good artist that it doesn't need to be articulated in words, Mary.

$[M M]$ That's an easy way out. Thank you!

$[E W]$ The last thing I wanted to touch on was, a few years ago you had work in the Noguchi [Museum] exhibition, Civic Action ${ }^{2}$ where notions of public action and art intersected. I was wondering if you could describe the publicness of your work and its role within being active, invoking action.

[MM] I really like that project, Ravenswood, CALL: If Only the City Could Speak [see Figure 9]. And again, I think it lays out an interesting scenario: here was this area of New York City, Long Island City, that was under pressure from developers. And the question was: 'What is the alternative scenario to the usual development?' I really hoped that the two cultural institutions that were sponsoring that show, the Noguchi Museum and Socrates Sculpture Park could get the attention of powers that be, to say, 'Why don't we think about this area differently, and let it be an R\&D [research and development] zone for new ways of living in the city? It could be a place where artists and designers could collaborate with scientists and others to come up with

\footnotetext{
${ }^{2}$ A two-part exhibition, Civic Action: A Vision for Long Island City, organised by the Noguchi Museum and Garden Museum in collaboration with Socrates Sculpture Park (2011-2012).
} 


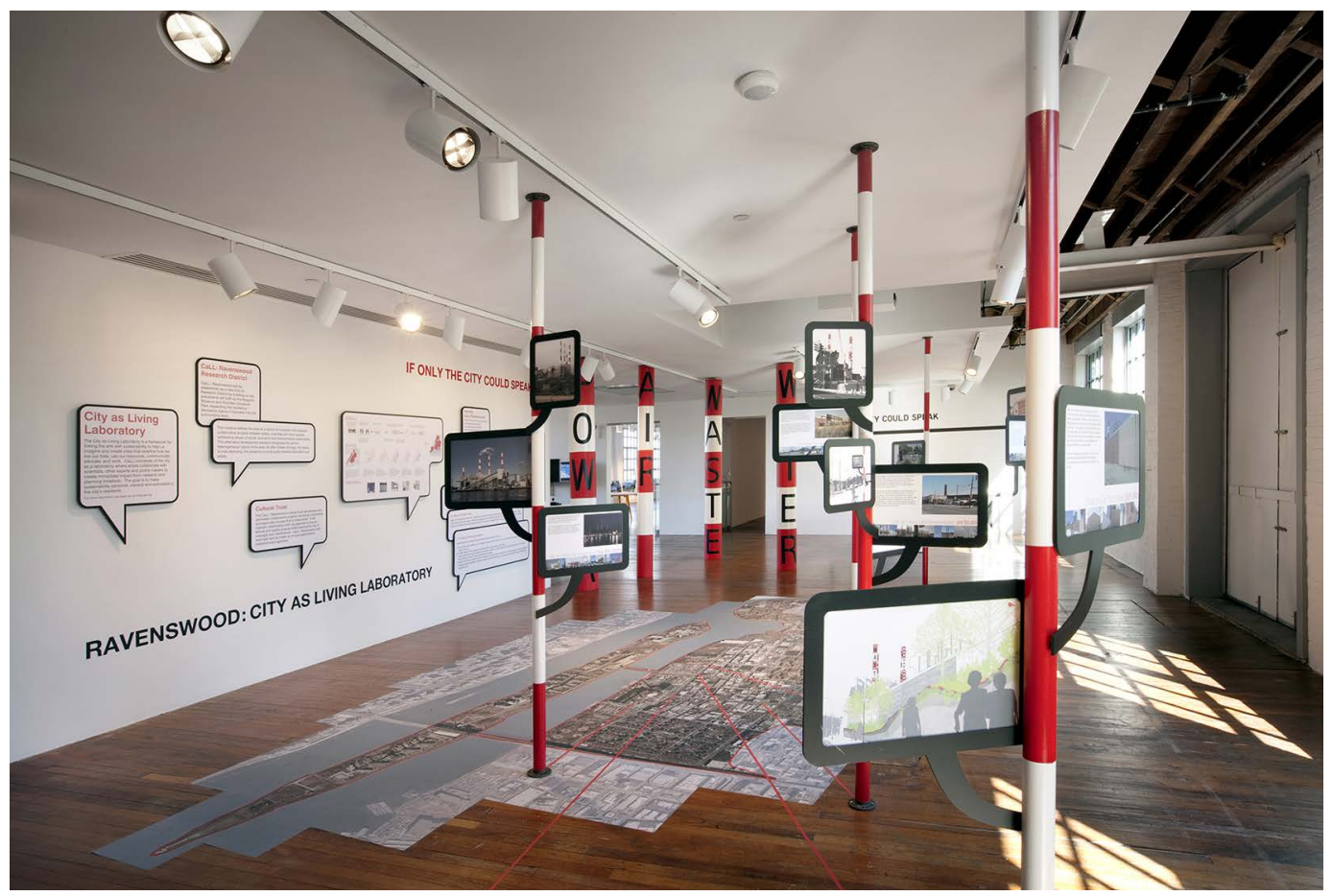

Figure 9. R/Call: If only the city could speak, Ravenswood [City as Living Laboratory].

ideas to be tested?' I think one of the great frustrations of trying to create change is the resistance that you confront in cities. That caution may seem necessary but it's so ingrained in cities and city governments, that change is almost impossible. To try and do anything new is so fraught with questions about liability. What if there was a part of the city where things could be tested out to see if they worked? I feel like we have to push our boundaries, and not stick to what the codes currently have outlined. You have to believe that there are some alternatives that we can begin to look at. And, yes, we have to make sure they're safe. And yes, we have to test them. But couldn't there be as a zone in the city where you could have the ability to go and check these ideas out, have people come and see what they're like, have companies invest money in supporting research of something that they're interested in?

[The open-endedness of the $C A L L$ projects is essential for this testing that Mary Miss describes. Cities have consistently been places of experimentation, sites where technologies, policies, and architectures have been first deployed. The structure of $C A L L$ projects as long-term engagements with people, places, and policy - embedded in communities while engaging with global agendas - provides inventive platforms from which testing, assessment, and development can be achieved. Few artists and designers have been able to dedicate extended periods of time to places and 
communities. Along with Ukeles whose work with the New York City Department of Sanitation (1977 - ) has spanned decades, or the landscape architect Joanna Gibbons who designed and continues to advocate for the Dalston Eastern Curve in London (2007-), the grounded nature of $C A L L$ projects is unique. If $C A L L$ works as city governance, as social infrastructure, and as situated conversations it is only achieved through the long-term commitment and endeavour of Mary Miss and her team of artists and scientists who work with people and places of each $C A L L$ project.]

$[M M]$ Let me just mention one other project, because you were asking about cities. I spent about a year at the Department of Design and Construction as the artist in residence - it was part of the programme that was initiated by the Department for Cultural Affairs when Tom Finkelpearl was the commissioner, having 'artists in residents' in various city agencies. And in this year, I had attended lots of meetings, and I tried to understand how more artists could be involved in the making of cites. There is a percent for art programme in New York City, but since the '70s, there have only been 300 art projects done in that period of time [while] there have been thousands of capital projects in the city every year. I wondered if there could be a way that artists could be integrated into more projects, for instance, even a modest replacement of a waterline in a street in a remote corner of Bedsty [Bedford-Stuyvesant, Brooklyn, New York].

So much of the city's work is about disruption. In Lower Manhattan we are still undergoing the process of the streets being dug up for reconstruction decades after it started after 9/11. It's like confronting the Grand Canyon around every corner you turn. But what if people could understand better what this infrastructure is doing for them in their lives, and if artists could help tell the story or connect people with what is happening. To do that, could we link artists who are interested in these issues with cultural agencies in the neighbourhoods, whether these are a library or a school or an arts organisation? Is there a way that what artists do, and how they think, could help to connect people with the natural systems and infrastructure that supports their lives? Could this kind of work be integrated across the city, whether it is a $\$ 3$ million project or a $\$ 300$ million dollar project? Not for every single project, but there seem to be many situations that would seem to lend themselves to this approach. Many more than the mere 300 [projects] that have been done would be possible.

So, the arts residency was, I think, a chance to think through how artists could be integrated into the city's building projects, to show that it is possible. At the end of my tenure the commissioner resigned, so it [has remained] just a proposal. But I think it was something interesting to think through and work on. 
$[E W]$ These connections between the infrastructures, that often lie hidden, with more natural systems and urban lives, in a conversation - that does not happen enough.

$[M M]$ Yes, infrastructure is what connects us with the natural systems [that] support our lives. I think that people should come to appreciate both more than they do.

\section{Acknowledgements}

I would like to thank Mary Miss for sharing her time and conversation about the $C A L L$ projects, as well as Georgina Fitzgibbon at the British Academy for her generous support.

\section{References}

CALL (2021), Watermarks. https://www.watermarksmke.org/ (accessed 27 July 2021).

Krauss, R. (1979), 'Sculpture in the Expanded Field', in October 8, 31-44. https://doi.org/10.2307/778224 Lynch, K. (1964), The Image of the City (MIT Press).

Miss, M. (2021), 'Mobility and Cultural Agency', paper presentation at AIANY (American Institute of Architects, New York) [27 January 2021].

Ukeles, M.L. (1969), Manifesto for Maintenance Art, 1969! Proposal for an Exhibition 'Care'.

Various (1973-1993), HERESIES: A Feminist Publication on Art and Politics.

Wall, E. (2017), 'Post Landscape', in E. Wall \& T. Waterman (eds), Landscape and Agency: Critical Essays (Routledge).

To cite the article: Ed Wall (2021), 'Constellations versus hero: a conversation with Mary Miss', Journal of the British Academy, 9(s5): 7-28. DOI https://doi.org/10.5871/jba/009s5.007

Journal of the British Academy (ISSN 2052-7217) is published by The British Academy, 10-11 Carlton House Terrace, London, SW1Y 5AH www.thebritishacademy.ac.uk 